\title{
FINANCIAL MANAGEMENT OF GAS AND ELECTRIC UTILITIES BY THE SECURITIES AND EXCHANGE COMMISSION*
}

\section{By Merwin H. Waterman \\ University of Michigan}

The title actually assigned to me for discussion on this occasion had a slightly more academic ring than the one I have chosen. I see no reason why, even before this group, a "spade" need be defined as "an elongated instrument by which perspiration and energy are applied to the movement of loose material from one place to another"; let's just call it a "spade." Let's recognize that the Public Utility Holding Company Act of $1935^{1}$ gave to the Securities and Exchange Commission managerial and directive powers in connection with the gas and electric utilities under its jurisdiction.

\section{Statutory Basis for Financial Regulation}

Before we examine or attempt to appraise the actual results of S.E.C. financial management let us briefly review the statutory directives under which the Commission operates. This review will provide the outline for my subsequent discussion of the Commission's exercise of its discretionary powers under the law. We all understand that the technique of exercising control over the financial affairs of utilities by the S.E.C. is accomplished by, first, a requirement of registration of all public utility holding companies, ${ }^{2}$ second, the requirement that registered holding companies and their subsidiaries can proceed with certain financial transactions only after the declaration describing a proposed transaction has been either exempted or made effective by order of the Securities and Exchange Commission, 3 or, third, the exercise of the Commission's power to direct those transactions incident to the disintegration of holding company systems.4 Please bear in mind that these controls extend only to those operating gas and electric utilities and holding companies falling within the jurisdiction of the law on the basis of a statutory 10 per cent voting security relationship between parent and subsidiary companies.

*Editor's Note: Professor Waterman's paper and the discussions by Professors Hall and Troxel which follow it were given at the meeting of the Transportation and Public Utilities Section of the American Economic Association held in Chicago on December 30, 1947. Because the paper and discussions are certain to be of interest to the members of the American Finance Association, decision has been made to include them here.

1 Public Act No. 333, 74th Congress.

2 Ibid, Sec. 5.

3 Ibid., Sec. 6, 7, 10, 12.

IIbid., Sec. 11. 
Section 7 of the Holding Company Act comprises the heart of statutory control over issuance of utility securities. It is this section which at once prohibits the use of no-par stock and unsecured bonds for new financing by other than operating utilities 6 and at the same time grants to the S.E.C. discretionary control over all issues in light of such circumstances as the adaptability of each security issued to the over-all financial structure, the earning capacity of the issuer, and the underwriting fees paid in connection with a public offering. ${ }^{7}$ In fact this section of the Act sounds like the outline of an academic course in financial management designed to indoctrinate students of business in the principles of finance which company managers should apply in connection with their capital-raising activities.

The scope of the S.E.C.'s powers of financial management is further extended by Section 10 of the Act which subjects the acquisition of utility assets and securities by a holding company or an operating unit to the scrutiny of the S.E.C. The Commission has the authority hereunder to pass judgment on prices and value, 8 and to prescribe terms and conditions to utility acquisitions, including the right to determine what is a reasonable price that one utility may pay for an interest in another.9

The same sort of directive powers with respect to the sale of assets and securities by a holding company are handed to the S.E.C. by Section 12 of the Act which empowers the Commission to condition any such sale in terms of prices, fees, and commissions. 10 Under this section, also, all intra-system loans are prohibited except as conditioned by the Commission and any funds paid for retirement of securities or payment of dividends either by an operating company or by a holding company can be accomplished only as directed by rule or by order of the Commission.11 By indirection, the S.E.C. is given vast discretionary powers over financial management under the divestment provision of the Holding Company Act. The disposition of holding company assets obviously necessitates determination of value and price, and the S.E.C. is the final determinant in deciding what is "fair and equitable to the persons affected by such a [divestment] plan."12

GIbid., Sec. 7(c) (1) (A) and (B), read with Sec. $7(c)(2)(A)$ and (B).

11bid., Sec. 7 (d) (1), (2), (3), (4).

8 Ibid., Sec. 10 (c) (1).

Ibid, Sec. 10 (e).

10Ibid., Sec. 12 (d).

11Ibid., Sec. 12(b) and (c).

12Ibid, Sec. $11(\mathrm{e})$. 


\section{Administrative Discretion by the S.E.C.}

This evidence is sufficient to establish the fact that the S.E.C. does have managerial authority over the financial affairs of the utilities under its jurisdiction via the Public Utility Act of 1935. It is incumbent on the Commission to administer its statutory responsibilities and thus to inject itself into the management of the utilities. It does so by rule and by order. Perhaps the prime example of management by rule is the well-known Rule U-5013 which requires competitive bidding for all utility securities destined for public sale and derives its authority from the Commission's power to regulate prices and underwriting fees in connection with security sales.

It is impossible in the time allotted either to the preparation or reading of this paper to accomplish a comprehensive survey of the S.E.C.'s managerial policies and activities bearing on public utility finance. My purpose will be accomplished if I can describe a few leading situations with which the Commission has dealt and comment on them in a way that will stimulate thought and discussion.

First I would like to present a case which I think typifies the managerial attitude of the S.E.C. with respect to utility financial structures. Late in 1939 Consumers Power Company filed a declaration under Section 7 of the law proposing to sell bonds publicly and to sell common stock to its parent, Commonwealth and Southern Corporation.14 Section 10 of the Act was involved also in Commonwealth's acquisition of its subsidiary's common stock. In a divided decision of the S.E.C. the right of Consumers Power Company to sell all of the requested $\$ 28,594,000$ of bonds was denied; that portion $(\$ 18,594,000)$ designed to refinance an existing issue was cleared as an interest-saving refunding operation.15 Even the $\$ 10,000,000$ was technically approved as being "for the purpose of financing the declarant as a public-utility company," 16 but this additional amount did not pass muster by the Commission in the exercise of its managerial judgment that these bonds were "necessary or appropriate to the economic and efficient operation" of Consumers Power Company.17 The Commission

13General Rules and Regulations under the Public Utility Holding Company Act of 1935 (U. S. Government Printing Office), 1946.

14Holding Company Act, Release No. 1854.

15Public Act No. 333, 74th Congress (PUHC Act); Section 7(c) (2) (A). 16 Ibid., Sec. T(c) (2) (B).

17Ibid., Sec. T(d) (s). 
majority decision in this matter rested on the fact that the company's balance sheet debt ratios would be higher than those of other utilities, and thus not "appropriate," and on the further fact that since common stock could be sold to raise an equivalent sum, the use of bonds was not "necessary." This was distinctly a managerial decision rendered in face of the fact that investment bankers stood ready to buy the total amount of bonds at a price to cost the company 3.07 per cent per annum, that interest coverage pro forma would be three times, and that leverage benefits would undoubtedly accrue both to preferred and common stock because the new funds would be added to a working investment which, in 1939, was earning 5.5 per cent on a total pro forma capitalization of $\$ 255.5$ million.

Dissenting Commissioners18 did not agree that the $\$ 10,000,000$ issue of "new money" bonds was either unnecessary or inappropriate. It is significant that this disagreement serves to emphasize the managerial function of the S.E.C.; the arguments presented on the matter, if not couched in such formal and legalistic language, would have sounded like arguments among company directors in the process of determining financial policy.

Whether the managerial influence of the S.E.C. on the capital structures of utilities under its jurisdiction is consistently sound by virtue of its method of testing almost exclusively by balance sheet ratios is a serious question. Although the personnel of the S.E.C. "board of directors" (Commissioners) has completely changed since the days of the case described above, decisions on similar matters have been settled by similar reasoning, and we find a most recent case clinging to the same standards. In passing judgment on the indenture provisions of a bond issue by Duquesne Light Company 19 the Commission insisted on a change in those provisions which would freeze surplus at a figure higher than that which the company proposed, thus limiting more restrictively the possibilities of future dividend payments. This move was justified by the S.E.C. as a means "to protect bondholders against diminution of the properties securing the debt" 20 and apparently ignored the pro forma fact that bond interest was being earned 5.99 times.21

18Healy and Mathews, Commissioners.

19Holding Company Act, Release No. 7712.

20Ibid., p. 6.

21 lbid, p. 5. 
All this leads to my conclusion that the S.E.C. places unwarranted faith in book values of assets and gives insufficient weight to real financial ability to pay out on security contracts. It may be true that some relationship does exist between the now dehydrated property accounts of operating utilities and expected future earnings, but to pretend that those assets have any real value beyond their earning capacity is not realistic. Real protection to bondholders and real value to stockholders rest squarely on ability to pay which in turn depends on earning power. If the S.E.C. is

correct in setting its "appropriate" capitalization standards in terms of ratios of principal amounts to book asset figures at a time when money rates are measured by 2.70 per cent to 3.00 per cent interest and 3.50 per cent to 4.00 per cent preferred dividends, how effective would those standards be, should we return to interest rates of the nineteen-twenties which might double these contractual money costs? It is assumed that the S.E.C. is advocating conservative standards, but if 50 per cent debt is conservative at 3 per cent money costs, it cannot be conservative at 6 per cent rates.

It is not my suggestion that the principal amount of debt should be ignored in determining what is sound financial management of utility capital structures; it is my contention that, in the exercise of its discretion, the S.E.C. should take a more realistic view of the basic factor of value in utility situations, namely, earnings. If, then, the S.E.C. and the utilities wish to preserve those values against the deterioration which has characterized railroad securities they could better agree to programs of future debt retirement in static or contracting situations which would require reduction of capitalization from the top down.

Commissioner McEntire has well put the financial problem of public utilities confronted with tremendous needs for capital expansion. He reasonably requests that the financing of these capital needs be kept on a sound basis. 22 It is my hope that management by the utilities, by the S.E.C., and by state regulatory authorities will measure this soundness by value and not by book costs, even though these book figures may have the blessing of both the S.E.C. and the Federal Power Commission. At best such so-called asset figures are but interesting historical facts; interest,

22"An Analysis of the Capital Structure of Electric Utilities Yesterday, Today and Tomorrow", Address of Richard B. McEntire, Commissioner, Securities and Exchange Commission, before the National Association of Railroed and Utilities Commissioners at Boston, Massachusetts, July 17, 1947. 
dividends and principal will be paid in the future out of funds derived from future operations and earnings.

I have mentioned previously the responsibilities of the S.E.C. under Section 10 of the Holding Company Act, the chief of which is to exercise its judgment with respect to values of utility securities when bought or sold by companies under the Holding Company Act jurisdiction of the Commission. In this connection it is interesting to note that earnings comprise the entire basis for the Commission's determination. In September of this year the S.E.C. approved the purchase by a registered holding company (Pennsylvania Power and Light Company) of three small operating utilities23 whose net property "values," as expressed in terms of original cost less depreciation, equaled $\$ 492,000$. The purchase of complete interest in these properties was approved at a base price of $\$ 675,000$, this being 12.2 times the current average net income of the combined companies! Apparently value for purchase and sale was based on a concept different from that of the value in support of corporate securities. This is not an isolated instance, but a fair reflection of the S.E.C.'s attitude toward value in such cases. In January, 1947, the Commmission approved the sale of a gas company whose depreciated original cost was $\$ 883,000$ at a price of $\$ 361,000.24$ The logic of a decision of this sort is apparent in face of the fact that future average earnings, after investing $\$ 126,000$ more capital, were estimated at only $\$ 28,000$. I trust, however, that should occasion arise the Commission would not approve $\$ 504,500$ of bonds, this amount being 50 per cent of the net cost including the new investment.

As a matter of fact I doubt that there are any real grounds for distinguishing between "valuation for capitalization" and "valuation for purchase and sale" in the public utility industry. I can think of no business situation where there is greater significance in future earning capacity and correspondingly less in historical cost when it comes to judging the position of creditors and owners; there could be nothing more hapless than a utility without earning capacity but with a fancy capitalization based on cost. It is true that our utility regulatory system looks largely to cost in the regulation of rates and earnings, but regulation operates primarily to set a ceiling and not to provide a subsidy in support of earnings. The cold economic facts of life in this respect are amply demon-

${ }^{23}$ Holding Company Act, Release No. 7749.

24 Holding Company Act, Release No. 7144 (re sale of gas utility asoets by New Jersey Power and Light Co.). 
strated in the history of the interurban railways and perhaps in the railroad field.

Thus in its ventures into the management of utility financial structures the Securities and Exchange Commission may be accused of some lack of realism and some lack of consistency. It is suggested that within its broad administrative powers the Commission could apply the dictates of sound finance based on the real source of economic value, namely, earning power. Capital structures fitted to the future earning potentials of utilities could be regulated more realistically, and in case of a downward trend of future earnings such a basis would prove more flexible and more susceptible to a necessary reduction of debt.

\section{The Problem of Competitive Bidding}

In the short time alloted to this paper I hesitate even to mention the words "compulsory competitive bidding." Yet the imposition of Rule U-50 by the S.E.C. certainly represents a significant inroad into the realm of utility financial management. In general this rule requires that all securities offered for sale by utilities under the Holding Company Act jurisdiction of the S.E.C. shall be submitted for competitive bidding, and I would like to provoke some discussion on this subject.

May I raise the question whether competitive bidding is effective as a substitute for sound financial management? May I question whether it leads to compliance with that provision of the Holding Company Act which stipulates that the interests of investors be considered in the process of regulation?25 May I further wonder whether the consumers and general public have benefited materially from competitive bidding operations? These are questions that I raise but do not answer, because I am not completely satisfied in my own mind as to the proper reply.

When I see a series of competitive bids for high-grade utility bonds such as that for the Detroit Edison issue of September, 1947, and find four offers ranging all the way from a low basis of $\mathbf{2 . 7 2 4 3}$ per cent to a high of 2.7473 per cent, I wonder "what the heck." Even on $\$ 60,000,000$ the difference would mean a saving of only $\$ 13,800$ per annum in interest cost, certainly a pittance per share on the company's 10,000,000 common shares outstanding and not very much per customer per year for possible division among some

26Public Act No. 333, 74th Congress, Section 1 (b). 
85,000 customers. Further, crediting the management of the company with more than a modicum of managerial intelligence, I cannot but assume that a negotiated sale would have been effected at or near the long-term government bond interest rates which were prevalent for high-grade utility bonds early in September of 1947.

From the standpoint of the investor there is nothing in competitive bidding which protects him from the risks of changing money rates inherent in high-grade, low-yield securities. The original purchasers of these Detroit Edison bonds, for instance, paid $\$ 101.125$ on a 2.70 per cent yield basis, and on this date (November 14,1947 ) they see their investment priced at 100 on a 2.75 per cent yield basis. This represents a loss of 1.125 points on the sale value and aggregates a loss of $\$ 675,000$. Although this same or greater loss might have occurred following a negotiated sale, I am only emphasizing that the pressure for the last nickel resulting from competitive bidding certainly does nothing to minimize the risk to the investor whose welfare is specifically mentioned in the statute as a charge to the Securities and Exchange Commission.

Coincident with the advent of competitive bidding there has been a marked reduction in bankers' spreads incurred in the distribution of utility securities. It should be noted, however, that the downward trend of spreads had begun before May, 1941, when Rule U-50 went into effect. According to the compilation of the S.E.C. staff 26 the weighted average spread for bonds (secured) in $\mathbf{1 9 3 6}$ was 2.16 points from whence it headed generally downward to 1.70 points in 1940. Since then the average spread for like securities has further declined to a low of .62 points in 1942 and up to .83 points in 1946. Again, if we can assume some degree of bargaining skill on the part of utility managements, it is likely that this same trend would have developed in negotiated deals under market conditions which were increasingly influenced throughout deals under market conditions which were increasingly influenced throughout this period by direct placements and institutional investment demands. Incidentally, it might be noted that a reduction of spread from 1.70 to .60 points on a typical thirty-year bond issue would approximate a reduction in money cost of .033 (thirtythree thousandths) of 1 per cent per annum on an amortized basis.

20"Security Issues of Gas and Electric Utilities, 1935-46," Report of Public Utilities Division, Securities and Exchange Commission (May 22, 1947). 
When we move from these considerations affecting high-grade bonds to the circumstances surrounding the bidding for lowergrade securities such as preferred and common stocks we encounter the fact that under uncertain market conditions bids are not always forthcoming. So far these cases have been neither numerous nor serious, but they do suggest the difficulties inherent in pricing risk securities in an unstable market. It seems only natural that the processes of valuation of higher risk securities should result in wider differences of judgment at all times and at some times so little confidence in any judgment that bids might be unjustifiably low or completely absent. The Securities and Exchange Commission itself so found recently and denied permission for the sale of common stock by Interstate Power Company in connection with that company's reorganization plan. ${ }^{27}$ Interstate received two bids for its common stock from an invitation designed to raise $\$ 8,635,500$ of equity money; the high bid was $\$ 4.05$ per share, the low was \$3.872422. The Commission determined that even the high price "would not effectuate a plan which would be fair and equitable to the persons affected thereby." These bids, incidentally, were made by bankers at a time when the Dow Jones utility stock average had just passed through 35 along with a general market unsettlement (September 7, 1947).

Therefore, I can only conclude with questions about compulsory competitive bidding. Does it guarantee or even tend to assure that necessary financing can be consummated at prices and yields that are realistic? How can it significantly affect the cost of capital at the high-grade security level, if one assumes honest and reasonably intelligent utility management?

\section{Conclusions}

In all, the decade of experience in financial regulation of gas and electric utilities by the Securities and Exchange Commission as affecting capitalizations, values, and security distribution, can not be marked as a period of operation which proves either the infallibility of S.E.C. management or even an improvement over private management. That utility managements have perhaps been more widely awakened to their financial responsibilities through association with the Public Utility Division of the S.E.C. may have been an incidental and beneficial result. These managements may have bestirred themselves to improve their financial

${ }^{27}$ Holding Company Act, Release No. 7739. 
status more expeditiously than they might otherwise have done.

Let us credit the S.E.C. with the origination of a beneficial stimulus. But it does not follow that the Commission's standards of financial management have been uniquely or consistently sound. As the Commission loses jurisdiction over gas and electric utilities I do not fear that financial standards will necessarily deteriorate. More do I fear that deterioration of standards may result from lack of motivation for management to do its best job under the arbitrary and unrealistic concepts born of the regulatory statutes and administered by the regulatory commissions.

\section{DISCUSSION}

JAMres K. Hall: Professor Waterman has directed his attention to the financial control exercised by the Securities and Exchange Commission over public utilities under the authority of the Public Utility Holding Company Act of 1935. He has briefly outlined the statutory character of this control and its implementation by the S.E.C. He concludes that the Commission not only engages in the function of utility financial management, but is compelled to do so under the Act. With this we would agree. He appraises a decade of S.E.C. control over the finances of the gas and electric utilities which come within the purview of the Commission's authority. In his judgment decisions of the S.E.C. regarding utility capitalizations, values, and security distribution have not proved to be of a better order than those of private managements; further, that as S.E.C. jurisdictional control recedes deterioration in the financial standards of private managements is not to be anticipated. On the other hand, Professor Waterman is prepared to credit S.E.C. utility financial control with good moral effect on private managements in making them more aware of their responsibilities.

S.E.C. decisions relating to utility capital structures in which, apparently, judgments have been formed largely on the basis of balance sheet ratios and not on earning capacity are questioned. It is Professor Waterman's view that "the S.E.C. places unwarranted faith in book values of assets and gives insufficient weight to real financial ability to pay out on security contracts." In support of this contention he cites the S.E.C. decision in the Consumers Power Company case ${ }^{1}$ which involved Sections 7 and 10

1 Securities and Exchange Commission Decisions and Reports 444 (Dec. 28, 1939). The Consumers Power Company is an operating public utility with its operations confined to the State of Michigan. 